\title{
PENGEMBANGAN PERANGKAT PEMBELAJARAN TERPADU MODEL NETWORKED TERINTEGRASI PLACE-BASED EDUCATION DI SEKOLAH DASAR
}

\author{
${ }^{1}$ Sukiyem Windariyah, ${ }^{2}$ Prabowo, ${ }^{3}$ Wahono Widodo \\ ${ }^{1}$ Mahasiswa Program Pascasarjana, Prodi Pendidikan Dasar, Universitas Negeri Surabaya, \\ ${ }^{2 \& 3}$ Dosen Pascasarjana, Prodi Pendidikan Dasar, Universitas Negeri Surabaya \\ e-mail: windarisuki@gmail.com
}

Received : November 2017

Reviewed : Desember 2017

Accepted : Januari 2018

Published : Januari 2018

\section{ABSTRACT}

The aim of this research is develop comprehensive instructional design plan of networked learning which integrated place-based education in elementary school with topic is The Healthy and Nutritious Food. This is developmental research with Kemp's model. Implementation's design using one group pretest-posttest design. The approach of this research is qualitative descriptive. The subject of this research is comprehensive instructional design plan of networked learning which integrated place-based education in elementary school and implementation's subject is the fourth grade students of SD Negeri Karangrena 02, Maos, SD Negeri Slarang 02, and SD Negeri Slarang 04, Kesugihan, Cilacap, in Central Java. The result of this research is a comprehensive instructional design plan of networked learning which integrated place-based education in elementary school is eligible for use in study and can improve outcome learning with a good instructional learning process.

Keyword: A Comprehensive Instructional Design Plan, Networked Learning, PlaceBased Education, Elementary School.

\section{ABSTRAK}

Penelitian ini bertujuan untuk mengembangkan perangkat pembelajaran terpadu model networked terintegrasi place-based education yang layak dengan topik makanan sehat dan bergizi untuk digunakan di sekolah dasar. Penelitian ini merupakan penelitian pengembangan, dengan model Kemp. Desain uji coba terbatas menggunakan one group pretest-posttest design dengan teknik analisis deskriptif kualitatif. Subjek penelitian adalah perangkat pembelajaran terpadu model networked terintegrasi place-based education di sekolah dasar. Sasaran uji coba terbatas adalah siswa kelas IV SDN Karangrena 02, Desa Karangrena, Kecamatan Maos, Kabupaten Cilacap, Provinsi Jawa Tengah, dan sasaran ujicoba luas adalah siswa kelas IV SD Negeri Slarang 02, SD Negeri Slarang 04, Desa Slarang, Kecamatan Kesugihan, dan SD Negeri Karangrena 02 Desa Karangrena, Kecamatan Maos, Kabupaten Cilacap, Provinsi Jawa Tengah. Hasil penelitian menunjukkan perangkat pembelajaran terpadu model networked terintegrasi placebased education di sekolah dasar sangat layak dan dapat digunakan di sekolah dasar serta dapat meningkatkan hasil belajar siswa melalui proses pembelajaran yang berkualitas.

Kata kunci: Perangkat pembelajaran, pembelajaran terpadu model networked, place-based education, sekolah dasar.

\section{PENDAHULUAN}

Permasalahan kualitas pembelajaran di Sekolah Dasar, ketidaksesuaian pembelajaran dengan kurilulum 2013 dan karakteristik siswa SD, dan padatnya jadwal siswa berdampak buruk pada hasil belajar dan diri peserta didik, siswa mungkin bisa menjadi pandai karena pembelajaran hanya mementingkan ketercapaian kemampuan kognitif saja namun sikap dan keterampilan siswa tidak diperhatikan, siswa juga terasing dari lingkungannya. Permasalahan tersebut harus segera 
dicarikan solusinya. Peneliti lebih menyarankan dan memilih mengembangkan perangkat pembelajaran daripada melakukan PTK dengan harapan mampu menyelesaikan masalah secara sistemik holistik. Perangkat pembelajaran yang dikembangkan diharapkan dapat menjadi alternatif pembelajaran yang menyenangkan dan membuat siswa betah dalam belajar, menumbuhkembangkan minat dan rasa ingin tahu, melibatkan siswa secara aktif dalam proses pembelajaran. Pembelajaran memberi kesempatan kepada peserta didik sebagai pembelajar untuk mengembangkan penalaran dan kreativitas serta mengintegrasikan sikap, kepribadian, serta mampu mengamalkannya dalam kehidupan sehari-hari Perangkat yang dikembangkan adalah perangkat pembelajaran terpadu dengan mengunakan model networked yang terintegrasi dengan place-based education.

Pembelajaran terpadu dipilih karena pembelajaran ini memerhatikan kebutuhan anak sesuai dengan perkembangan peserta didik, melibatkan siswa secara aktif dalam proses pembelajaran baik fisik maupun emosionalnya, mewadahi cara berfikir peserta didik di jenjang Sekolah Dasar yang masih bersifat holistik. Pengintegrasian place-based education dengan model networked dilakukan dengan alasan pembelajaran model networked dan place-based education memiliki kecocokan karakteristik. Keduanya menggunakan komunitas lokal dan berdasarkan minat peserta didik. Komunitas lokal di sekitar lingkungan yang membantu dalam pembelajaran ini adalah ahli masak dan gizi dan narasumber lain seperti petani dan ibu rumah tangga.

Pembelajaran terpadu model networked terintegrasi place-based education bisa diajarkan kepada peserta didik jika dan hanya jika guru memiliki perangkat pembelajaran. Perangkat pembelajaran adalah alat, bahan, media, petunjuk, dan pedoman yang diperlukan dan akan digunakan untuk mengelola pembelajaran yang terdiri atas Silabus, Rencana Pelaksanaan pembelajaran (RPP), Bahan Ajar, Lembar Kegiatan Siswa (LKS) dan Tes Hasil Belajar (Ibrahim, 2002:3). Pembelajaran terpadu adalah pendekatan pembelajaran yang memadukan beberapa standar kompetensi ke dalam satu atau beberapa disiplin ilmu (Drake and Burn, 2004: 2). Model networked adalah salah satu model pembelajaran terpadu yang merupakan gabungan beberapa immersed dengan pembelajaran membutuhkan narasumber ahli yang membantu peserta didik memelajari sesuatu yang menjadi minatnya (Fogarty, 1991:96).

Place-based education adalah strategi pembelajaran yang menghubungkan peserta didik dengan lingkungan sekitar, kelas dan komunitas sebagai langkah awal untuk mengajarkan konsep bahasa dan seni, Ilmu Pengetahuan Sosial, Matematika, Ilmu Pengetahuan Alam, dan mata pelajaran lain dalam lintas kurikulum yang disusun berdasar a local context of interest - seperti sosial, budaya, politik, ekonomi, atau lingkungan alam. Placebased education digunakan dalam pembelajaran terpadu terutama model networked dengan melakukan penyelidikan, menumbuhkan rasa ingin tahu, dan pengalaman belajar di lingkungan, dunia nyata, peserta didik. Pendekatan pembelajaran ini dapat meningkatkan kemampuan akademik, membantu siswa mengembangkan kemampuan untuk masyarakat mereka, merubah penghargaan siswa untuk kehidupan yang alami, dan menciptakan komitmen yang tinggi untuk memberikan kontribusi secara nyata sebagai anggota masyarakat (Smith and Sobel, 2010:23).

Berdasar uraian tersebut, maka perangkat pembelajaran terpadu model networked terintegrasi placebased education adalah alat, bahan, media, petunjuk, dan pedoman berupa silabus, Rencana Pelaksanaan pembelajaran (RPP), Bahan Ajar, Lembar Kegiatan Siswa (LKS) dan evaluasi yang diperlukan dan akan digunakan untuk mengelola pembelajaran terpadu dengan bantuan ahli dan menggunakan strategi pembelajaran yang menghubungkan peserta didik dengan lingkungan sekitarnya. dengan harapan mampu mengakomodasi siswa yang benar-benar ingin belajar, membuat pebelajar belajar bagaimana belajar (learning how to learn) dan mengembangkan potensi di dalam dirinya secara optimal.

Pengembangan perangkat pembelajaran ini perlu dilakukan guru karena perangkat pembelajaran inilah yang akan dijadikan panduan bagi guru atau instruktur agar dapat memberikan pembelajaran yang efektif dan efisien bagi peserta didik. Perangkat pembelajaran terpadu model networked terintegrasi place-based education belum ada terutama di sekolah dasar negeri. Peneliti merasa perlu melakukan pengembangan perangkat pembelajaran terpadu model networked terintegrasi place-based education di Sekolah Dasar.

Berdasar uraian di atas, maka dilakukan penelitian dengan judul "Pengembangan Perangkat Pembelajaran Terpadu Model Networked Terintegrasi Place-Based Education di Sekolah Dasar".

Tujuan umum penelitian ini adalah menghasilkan perangkat pembelajaran terpadu model networked terintegrasi place-based education di Sekolah Dasar yang layak. Tujuan khusus penelitian ini dijabarkan sebagai berikut: 
1. Mendeskripsikan validitas perangkat pembelajaran terpadu model networked terintegrasi place-based education di Sekolah Dasar.

2. Mendeskripsikan keterlaksanaan rencana pelaksanaan pembelajaran terpadu model networked terintegrasi place-based education di Sekolah Dasar.

3. Mendeskripsikan tingkat keterbacaan bahan ajar siswa pada perangkat pembelajaran terpadu model networked terintegrasi place-based education di Sekolah Dasar.

4. Mendeskripsikan aktivitas siswa saat penerapan pembelajaran terpadu model networked terintegrasi place-based education di Sekolah Dasar.

5. Bagaimanakah hambatan penelitian dalam pengembangan pembelajaran terpadu model networked terintegrasi place-based education di Sekolah Dasar.

6. Mendeskripsikan respon siswa Sekolah Dasar terhadap kegiatan pembelajaran terpadu model networked terintegrasi place-based education di Sekolah Dasar.

7. Mendeskripsikan hasil belajar yang meliputi ranah kognitif, afektif, dan psikomotor setelah mengikuti kegiatan pembelajaran terpadu model networked terintegrasi place-based education di Sekolah Dasar.

Penelitian ini diharapkan memberi manfaat bagi pendidikan. Manfaat penelitian ini antara lain.

1. Menyediakan contoh perangkat pembelajaran terpadu model networked terintegrasi place-based education di Sekolah Dasar yang bisa dijadikan acuan pengembangan perangkat pembelajaran lain yang setipe dengan perangkat pembelajaran yang telah dikembangkan.

2. Memberikan pengetahuan tentang alternatif inovasi pembelajaran yang bisa dilakukan guru dengan mengembangkan perangkat pembelajaran yang relevan dengan pembelajaran bagi peserta didik yang hidup di abad ke-21.

3. Data dalam penelitian ini dapat dijadikan bukti autentik yang meyakinkan bahwa serumit apapun model pembelajaran dapat dilaksanakan dengan baik dan berakibat baik pada siswa sekolah dasar apabila dilakukan beberapa inovasi dan penyesuaian sesuai perkembangan peserta didik.

\section{METODE PENELITIAN}

Penelitian ini menggunakan pendekatan deskriptif kualitatif. Jenis penelitian ini adalah penelitian pengembangan yang bertujuan untuk mengembangkan perangkat pembelajaran terpadu model networked terintegrasi place-based education di Sekolah Dasar. Perangkat pembelajaran yang dihasilkan pada penelitian ini terdiri atas silabus, rencana pelaksanaan pembelajaran, bahan ajar siswa, lembar kegiatan siswa, dan evaluasi hasil belajar.

Prosedur penelitian ini dilakukan melalui dua tahapan. Tahap pertama yaitu pengembangan perangkat pembelajaran terpadu model networked terintegrasi placebased education dengan menggunakan pengembangan perangkat pembelajaran model Kemp yang peneliti modifikasi sesuai dengan kondisi penelitian. Ttahap kedua adalah melakukan ujicoba terbatas serta luas di tempat penelitian. Ujicoba luas dilakukan dengan mereplikasi pembelajaran ke tiga tingkatan kelas yang sama di tiga sekolah dasar yang berbeda. Desain yang digunakan untuk mengujicoba perangkat pembelajaran terpadu model networked terintegrasi place-based education di Sekolah Dasar ini adalah one group pretest-posttest design dengan rumus berikut ini.
U 1
$\mathrm{L} \rightarrow$
U2 (Prabowo, 2011:36)

Keterangan:

U1 : uji awal untuk mengetahui kemampuan awal siswa sebelum pembelajaran.

L : Proses pembelajaran terpadu model networked terintegrasi place-based education.

U2 : uji akhir untuk mengetahui penguasaan materi siswa setelah pembelajaran

Variabel penelitian terkait pengembangan adalah perangkat pembelajaran terpadu model networked terintegrasi place-based education. Variabel yang terkait kelayakan adalah validitas perangkat pembelajaran, tingkat keterbacaan bahan ajar siswa,keterlaksanaan RPP, aktivitas siswa, hambatan penelitian, respon siswa, dan hasil belajar siswa.

Definisi operasional variabel yang diidentifikasi dalam penelitian ini adalah sebagai berikut:

a. Validitas perangkat adalah skor hasil validasi yang diperoleh dari validator yang menunjukkan instrumen yang dikembangkan dapat dengan tepat mengukur semua aspek yang diukur dalam penelitian ini. Uji validitas perangkat pembelajaran dilakukan dengan menggunakan lembar validasi perangkat.

b. Keterlaksanaan Rencana Pelaksanaan Pembelajaran adalah persentase dan kualitas keterlaksanaan pembelajaran sesuai tahapan yang ada pada RPP yang dikembangkan menggunakan lembar pengamatan keterlaksanaan RPP.

c. Aktivitas siswa adalah persentase keterlibatan siswa dalam pembelajaran yang direkam menggunakan lembar pengamatan aktivitas siswa. 
d. Tingkat keterbacaan adalah persentase tingkat kemampuan siswa dalam membaca dan memahami isi bacaan pada bahan ajar siswa. Tingkat keterbacaan diukur menggunakan teks rumpang.

e. Hambatan penelitian adalah masalah yang ditemui dalam pengembangan perangkat maupun ujicoba yang dicatat menggunakan lembar pengamatan hambatan penelitian untuk dicari solusinya.

f. Respon siswa adalah tanggapan siswa terhadap pembelajaran yang dilakukan dengan pengisian kuisioner yang berisi instrumen yang terkait respon siswa terhadap pembelajaran yang telah dilaksanakan.

g. Hasil Belajar adalah hasil yang berupa nilai yang diperoleh siswa sebelum dan setelah pelaksanaan pembelajaran terpadu model networked terintegrasi place-based education menggunakan lembar evaluasi hasil belajar.

Subjek penelitian ini adalah perangkat pembelajaran terpadu model networked terintegrasi place-based education dengan sasaran ujicoba terbatas adalah siswa kelas IV SD Negeri Karangrena 02, Desa Karangrena, Kecamatan Maos, Kabupaten Cilacap, Provinsi Jawa Tengah dan untuk ujicoba luas dilakukan dengan replikasi di SD Negeri Slarang 02 dan 04, Desa Slarang, Kecamatan Kesugihan serta SD Negeri Karangrena 02, Kecamatan Maos Kabupaten Cilacap, Provinsi Jawa Tengah.

Tempat penelitian ini adalah di Universitas Negeri Surabaya dan SD Negeri Karangrena 02, Desa Karangrena, Kecamatan Maos, Kabupaten Cilacap, Provinsi Jawa Tengah serta SD Negeri Slarang 02 dan 04, Desa Slarang, Kecamatan Kesugihan, Kabupaten Cilacap. Penelitian ini dimulai pada bulan November 2015 dan direncanakan selesai pada bulan Juli 2016.

Teknik yag digunakan dalam pengumpulan data pada penelitian ini adalah validasi perangkat, pengamatan atau observasi, pengisian teks rumpang, penyebaran angket, pemberian tes, wawancara, dan dokumentasi. Teknik yang digunakan untuk menganalisis data dilakukan secara deskriptif dan inferensial. Analisis data yang dilakukan bertujuan untuk memberikan makna terhadap data yang telah dikumpulkan dari sampel penelitian dan menguji kelayakan perangkat pembelajaran baik validitas, kepraktisan maupun keefektifannya.

Instrumen yang digunakan dalam penelitian ini antara lain lembar validasi perangkat pembelajaran, lembar pengamatan keterlaksanaan rencana pelaksanaan pembelajaran, lembar pengamatan aktivitas siswa selama pembelajaran, lembar tingkat keterbacaan bahan ajar, lembar pengamatan hambatan penelitian, lembar angket respon siswa, dan lembar penilaian hasil belajar.

\section{HASIL PENELITIAN DAN PEMBAHASAN}

Hasil penelitian ini adalah perangkat pembelajaran terpadu model networked terintegrasi place-based education di Sekolah Dasar yang terdiri atas silabus, RPP, tiga buah LKS, Bahan Ajar Siswa dan Evaluasi Hasil Belajar. Perangkat tersebut kemudian diuji untuk mengetahui kelayakan perangkat pembelajaran yang dikembangkan mencakup validitas, kepraktisan, dan keefektifan. Hasil penelitian pada ujicoba terbatas dan luas secara lengkap diuraikan dalam penjelasan berikut ini.

Validitas perangkat pembelajaran yang dikembangkan dalam penelitian "Pengembangan Perangkat Pembelajaran Terpadu Model Networked Terintegrasi Place-Based Education di Sekolah Dasar" diketahui melalui hasil validasi yang dilakukan oleh dua validator ahli. Perangkat pembelajaran yang divalidasi meliputi silabus, Rencana Pelaksanaan Pembelajaran (RPP), Lembar Kegiatan Siswa (LKS), Bahan Ajar Siswa (BAS), dan evaluasi hasil belajar. Rekapitulasi skor hasil validasi perangkat pembelajaran terpadu model networked terintagrasi place-based education secara lengkap tersaji pada tabel 1 berikut ini.

Tabel 1 Rekapitulasi Hasil Validasi Perangkat Pembelajaran

\begin{tabular}{|c|c|c|c|c|c|}
\hline \multirow{3}{*}{ No } & \multirow{3}{*}{ Uraian } & \multicolumn{4}{|c|}{ Hasil Validasi } \\
\hline & & \multicolumn{2}{|c|}{ Modus } & \multicolumn{2}{|c|}{ Reliabilitas } \\
\hline & & Skor & Kategori & Persentase & Kategori \\
\hline 1. & Silabus & 3 & valid & $95,22 \%$ & Baik \\
\hline 2. & RPP & 4 & $\begin{array}{l}\text { Sangat } \\
\text { valid }\end{array}$ & $97,35 \%$ & Baik \\
\hline 3. & LKS & 4 & $\begin{array}{l}\text { Sangat } \\
\text { valid }\end{array}$ & $94,99 \%$ & Baik \\
\hline 4. & BAS & 4 & $\begin{array}{l}\text { Sangat } \\
\text { valid }\end{array}$ & $94,20 \%$ & Baik \\
\hline 5. & Evaluasi & 3 & Valid & $90,98 \%$ & Baik \\
\hline
\end{tabular}

Modus skor rata-rata hasil validasi perangkat pembelajaran adalah 4 dan reliabilitas rata-rata instrumen validasi perangkat pembelajaran yang dikembangkan baik dengan persentase $94,55 \%$ menunjukan perangkat pembelajaran yang dikembangkan sangat valid dan dapat digunakan dalam pembelajaran. Perangkat pembelajaran yang valid dapat dijadikan referensi autentik untuk dapat melaksanakan pembelajaran yang baik guna peningkatan kualitas pembelajaran yang dapat meningkatkan hasil belajar siswa di Sekolah Dasar.

Kepraktisan perangkat pembelajaran didapat dari hasil pengamatan keterlaksanaan rencana pelaksanaan pembelajaran, aktivitas belajar, dan hambatan penelitian serta tingkat keterbacaan bahan ajar siswa. Hasil ujicoba 
terbatas menunjukkan perangkat pembelajaran terpadu model networked terintegrasi place-based education praktis dan dapat digunakan dalam pembelajaran di Sekolah Dasar dengan keterlaksaan RPP yang sangat baik dengan kategori baik dengan skor 3,6, aktivitas belajar yang terpusat pada siswa, penilaian tingkat keterbacaan dengan $90 \%$ siswa berada pada tingkat independen, dan hambatan penelitian yang mampu diatasi dengan baik.

Kegiatan pembelajaran dalam RPP yang dikembangkan pada penelitian ini sesuai dengan teori belajar Gestalt, Bruner, Ausubel, Albert Bandura, dan Piaget. RPP secara keseluruhan dapat terlaksana pada ujicoba terbatas maupun luas. Tahapan kegiatan dalam RPP pada ujicoba terbatas terlaksana dengan kategori baik. Rekapitulasi Hasil pengamatan keterlaksanaan RPP pada ujicoba luas dapat dicermati pada Tabel 2 berikut.

Tabel 2 Rekapitulasi Hasil Pengamatan Keterlaksanaaan RPP

\begin{tabular}{|c|c|c|c|c|}
\hline \multirow{2}{*}{ No. } & \multirow{2}{*}{ Uraian } & \multicolumn{3}{|c|}{ Skor Hasil Pengamatan } \\
\hline & & KR 1 & KR 2 & KR 3 \\
\hline 1. & $\begin{array}{l}\text { Pelaksanaan } \\
\text { KBM }\end{array}$ & 3,5 & 3,8 & 3,7 \\
\hline 2 & Suasana Kelas & 3,5 & 4 & 3,8 \\
\hline 3 & $\begin{array}{l}\text { Pengelolaan } \\
\text { waktu }\end{array}$ & 3 & 3 & 3 \\
\hline \multicolumn{2}{|c|}{ Rata-rata } & 3,3 & 3,6 & 3,5 \\
\hline \multicolumn{2}{|c|}{ Reliabilitas } & $96,7 \%$ & $98,6 \%$ & $95,4 \%$ \\
\hline
\end{tabular}

Berdasar skor rata-rata dan reliabilitas keterlaksanaan RPP pada tabel tersebut dapat disimpulkan bahwa RPP dapat terlaksana dengan kategori baik sampai dengan sangat baik.

Hasil pengamatan aktivitas siswa pada ujicoba luas menunjukkan $99 \%$ aktivitas yang dilakukan siswa relevan dengan pembelajaran. Aktivitas yang dominan adalah membersihkan dan mengolah bahan makanan, melakukan pengamatan terhadap sumber daya alam, teknologi, dan hubungan dengan kondisi geografis di lingkungan, melakukan penyelidikan melalui eksperimen sederhana. Data tersebut menunjukkan kualitas pembelajaran yang baik dengan aktivitas pembelajaran berpusat pada siswa (student center).

Bahan ajar yang cocok untuk kelas IV SD berdasar ujicoba terbatas kemudian digunakan pada ujicoba luas. Hasil penilaian tingkat keterbacaan bahan ajar siswa pada ujicoba luas adalah kelas replikasi I SD Negeri Slarang 02, kelas replikasi II SD Negeri Slarang 04, dan kelas replikasi III SD Negeri Karangrena 02 secara lebih jelas terlihat pada gambar Grafik 1 berikut ini.

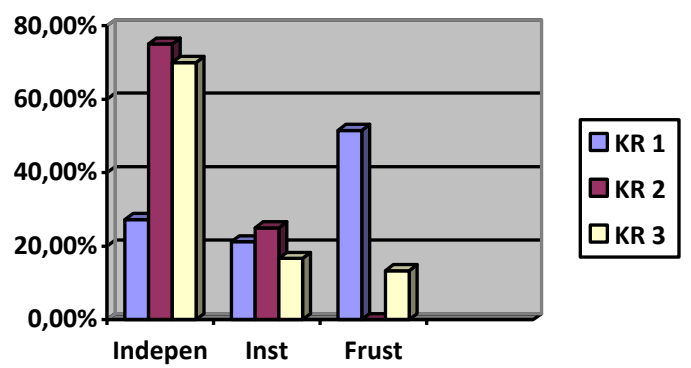

Gambar 1 Grafik Hasil Penilaian Tingkat Keterbacaan pada Ujicoba Luas

Gambar grafik tersebut menunjukkan tingkat keterbacaan kelas replikasi II SD Negeri Slarang 04, dan kelas replikasi III SD Negeri Karangrena 02 lebih baik daripada kelas replikasi I. Tingkat keterbacaan kelas replikasi I rendah dengan ditandai banyaknya persentase siswa yang berada pada tingkat frustasi yang berarti sebagian besar siswa di kelas tersebut belum mampu membaca dan memahami bahan ajar dengan baik.

Persentase tingkat keterbacaan siswa kelas replikasi II, dan III yang berada pada tingkat independen lebih banyak daripada tingkatan yang lain. Hal ini menunjukkan sebagian besar siswa di kedua kelas ini mampu membaca dan memahami bahan ajar dengan baik.

Rata-rata tingkat keterbacaan ketiga kelas tersebut adalah $57,25 \%$ berada pada tingkat independen, dan $42,74 \%$ berada pada tingkat instruksional dan frustasi. Berdasar data tersebut dapat disimpulkan bahwa sebagian besar siswa dapat membaca dan memahami bahan ajar dengan baik walaupun masih banyak pula siswa yang tidak mampu membaca dan memahami bahkan butuh bimbingan dalam membaca dan memahami bahan ajar yang dikembangkan.

Hambatan pada ujicoba luas baik pada persiapan maupun pelaksanaan disebabkan oleh beberapa faktor antara lain biaya, waktu, peralatan, sulitnya mendatangkan ahli, dan kesiapan guru dan siswa dalam pelaksanaan pembelajaran. Semua hambatan penelitian dapat diatasi dengan baik sehingga penelitian dapat berjalan dengan lancar menunjukkan pembelajaran terpadu model networked terintegrasi place-based education ternyata cocok diterapkan di Sekolah Dasar. Penelitian ini sekaligus menguatkan hasil penelitian pembelajaran terpadu model networked yang dilakukan oleh Limbong, Elymius (2013), dan Feldman (1991) yang memiliki kesamaan hasil yaitu model networked cocok dan sesuai untuk diterapkan di Sekolah Dasar. 
Keefektifan perangkat pembelajaran diukur dari respon siswa dan tes hasil belajar. Respon siswa terhadap pembelajaran terpadu model networked terintegrasi placebased education di Sekolah Dasar pada ujicoba terbatas sangat positif dengan persentase sebesar 92,67\%. Respon siswa pada ujioba luas secara rinci dapat dicermati pada tabel berikut.

Tabel 3 Rekapitulasi Respon Siswa

\begin{tabular}{llc}
\hline No & \multicolumn{1}{c}{ Uraian } & Ya (\%) \\
1 & Model pembelajaran terpadu model & 99,24 \\
& networked terintegrasi place-based \\
& education menyenangkan dan \\
& membetahkan serta mampu \\
& meningkatkan pemahaman materi. \\
2. & LKS & 86,59 \\
3 & BAS & 89,66 \\
4 & Evaluasi Hasil Belajar & 57,47 \\
\hline
\end{tabular}

Data pada tabel tersebut menunjukkan adanya respon siswa yang positif terhadap pembelajaran terpadu model networked terintegrasi place-based education. Siswa berpendapat pembelajaran yang dilakukan menyenangkan, mengasyikkan, dan membetahkan. Hasil penelitian Peter; Jones, Chris; Asensio Mireja; Vivien and Steeples, Christine (2005) memiliki kesesuaian dengan penelitian ini yaitu sama-sama menunjukkan bahwa pembelajaran model networked membuat siswa tetap merasa senang dan betah di sekolah.

Evaluasi hasil belajar meliputi hasil belajar kognitif, afektif, dan psikomotor. Ranah afektif dan psikomotor tidak diabaikan karena keterpaduan antara pengetahuan, sikap dan keterampilan mutlak adanya dalam penilaian yang sesuai dengan kurikulum 2013.

Hasil belajar holistik merupakan gabungan dari hasil belajar kognitif, afektif, dan psikomotor dengan perbandingan 50:30:20. Hasil belajar pada ujicoba terbatas menunjukkan hasil yang memuaskan dengan nilai rata-rata hasil belajar muatan pembelajaran IPA, Matematika, Bahasa Indonesia, dan IPS berturut-turut adalah 79, 80, 80 , dan 79

Hasil belajar holistik pada ujicoba luas pada pembelajaran kali pertama menunjukkan hasil yang masih belum optimal karena masih berada di bawah KKM nasional yaitu 75. Nilai Rata-rata hasil penilaian holistik pada ujicoba luas dapat diamati pada tabel 4 berikut.
Tabel 4 Rekapitulasi Hasil Pretest dan Posttest pada Ujicoba Luas

\begin{tabular}{cccccc}
\hline \multirow{2}{*}{ No } & Kelas & \multicolumn{4}{c}{ Rata-rata nilai } \\
& Replikasi & IPS & IPA & MTK & B.Ind \\
1. & I & 53 & 56 & 55 & 47 \\
2. & II & 66 & 66 & 65 & 74 \\
3. & III & 67 & 69 & 62 & 52 \\
\hline
\end{tabular}

Perolehan hasil belajar kognitif, afektif, dan psikomotor menunjukkan kompetensi yang berhubungan dengan pemahaman dan kepedulian terhadap lingkungan. Pemahaman dan kepedulian terhadap lingkungan akibat pembelajaran yang dilakukan pada penelitian ini memang belum maksimal. Adanya pemahaman dan kepedulian terhadap lingkungan yang terjadi setelah pembelajaran terpadu model networked terintegrasi place-based education memiliki kesamaan hasil dengan penelitian Altman, Stries, and Wessen dan Hutson, Garret; Muthersbaugh, Debbie; Kern, Anne L.; Charvoz, Rebecca (2014) yaitu Pembelajaran terpadu menggunakan placebased education berpengaruh terhadap peningkatan kepercayaan terhadap kemampuan untuk memahami dan memiliki kepedulian terhadap lingkungan.

Hasil pretest dan posttest pada ujicoba terbatas mengalami peningkatan hasil belajar yang signifikan. Peningkatan hasil belajar yang signifikan menunjukkan siswa pada ujicoba terbatas mampu menguasai konsep dengan baik. Hasil analisis sensitivitas butir soal pada ujicoba terbatas menunjukkan bahwa butir soal yang digunakan dalam penelitian ini memiliki sensitivitas yang tinggi yang berarti siswa dalam pembelajaran yang dilakukan pada ujicoba terbatas berhasil mencapai tujuan pembelajaran yang telah ditentukan. Hasil pretest dan posttest pada ujicoba luas dapat dicermati pada Tabel 5 berikut ini.

Tabel 5 Rekapitulasi Hasil Pretest dan Posttest pada

\begin{tabular}{|c|c|c|c|c|c|c|c|c|}
\hline & & & $\mathrm{Uji}$ & a & & & & \\
\hline \multirow{2}{*}{ KR } & \multicolumn{2}{|c|}{ IPS } & \multicolumn{2}{|c|}{ IPA } & \multicolumn{2}{|c|}{ MTK } & \multicolumn{2}{|c|}{ B.Ind } \\
\hline & Pre & Post & Pre & Post & Pre & Post & Pre & Post \\
\hline I & 40 & 30 & 34 & 35 & 13 & 32 & 20 & 15 \\
\hline II & 11 & 40 & 16 & 58 & 12 & 51 & 16 & 58 \\
\hline III & 21 & 70 & 9 & 59 & 13 & 44 & 3 & 28 \\
\hline $\begin{array}{l}\text { Rerata } \\
n \text {-gain }\end{array}$ & \multicolumn{2}{|c|}{0,26} & \multicolumn{2}{|c|}{0,35} & \multicolumn{2}{|c|}{0,34} & \multicolumn{2}{|c|}{0,23} \\
\hline
\end{tabular}

Berdasar tabel tersebut menunjukkan adanya peningkatan hasil belajar. Peningkatan hasil belajar pada ujicoba luas menunjukkan hasil yang kurang optimal dengan kategori rendah sampai dengan sedang. Peningkatan hasil belajar setelah mengikuti pembelajaran 
terpadu model networked terintegrasi place-based education di Sekolah Dasar menunjukkan perangkat pembelajaran ini efektif walaupun peningkatan belajar yang diperoleh belum optimal.

Hasil belajar yang meningkat tidak terlepas dari proses pembelajaran yang berkualitas. Pernyataan tersebut didukung oleh penelitian yang dilakukan oleh Bagus dan Dantes (2014) yang menyatakan bahwa kualitas pembelajaran berkontribusi sebesar $14,8 \%$ terhadap hasil belajar. Kualitas pembelajaran dapat dilihat dari keaktifan siswa mengikuti pembelajaran. Aktivitas siswa dalam pembelajaran ini menunjukan siswa aktif dalam pembelajaran yang membuat hasil belajar meningkat. Peningkatan hasil belajar setelah dilakukannya pembelajaran terpadu model networked terintegrasi placebased education menunjukkan kesamaan dengan hasil penelitian yang dilakukan oleh Murtiningsih (2007), Suryanti (2008); Haryati, Mala Ima; Kasdi Aminudin; Subroto, Tjipto Waspodo (2014), dan Khoironiyah, Muhari, dan Subroto, Tjipto Waspodo (2014) yang menunjukkan bahwa pembelajaran terpadu mampu meningkatkan hasil belajar.

Berdasar tabel rekapitulasi hasil pretest dan postest diketahui pula bahwa peningkatan hasil belajar tidak dialami oleh semua siswa pada semua kelas replikasi. Siswa di kelas replikasi I yang mengalami penurunan hasil belajar. Siswa seharusnya mengalami peningkatan hasil belajar setelah mengikuti pembelajaran yang berkualitas namun justru mengalami penurunan hasil belajar. Penurunan hasil belajar yang terjadi kemungkinan disebabkan karena penurunan stamina karena sehari penuh mengikuti pembelajaran yang menggunakan aktivitas fisik dan psikis yang banyak. Faktor yang lain adalah karena tingkat keterbacaan sebagian besar siswa pada kelas tersebut berada pada tingkat frustasi atau tidak mampu membaca dan memahami bahan ajar yang berakibat pada kesalahan interpretasi dan menafsirkan maksud soal yang berakibat pada kesalahan menjawab soal. Penelitian ini sekaligus mementahkan penelitian yang dilakukan oleh Sulistyorini (2006) yang menyatakan bahwa tingkat keterbacaan bahan ajar tidak berpengaruh terhadap prestasi atau hasil belajar. Berdasar hasil penelitian ini tingkat keterbacaan memengaruhi hasil belajar siswa.

Peningkatan hasil belajar pada ujicoba luas tidak serta merta menunjukkan adanya keberhasilan pencapaian tujuan pembelajaran pada setiap aspek kognitif. Keberhasilan pencapaian tujuan pembelajaran yang diukur menggunakan sensitivitas butir soal butir soal menunjukkan perbedaan sensitivitas butir soal pada kelas replikasi I, II, dan III. Rata-rata indeks sensitivitas butir soal kelas replikasi I, II, dan III adalah 0,03; 0,35; dan 0,34 menunjukkan siswa belum berhasil mencapai tujuan pembelajaran sedangkan siswa di kelas replikasi II dan III berhasil mencapai tujuan belajar.

\section{PENUTUP}

\section{Simpulan}

Hasil penelitian berupa perangkat pembelajaran terpadu model networked terintegrasi place-based education layak digunakan di sekolah dasar dengan validitas, kepraktisan dan keefektifan yang baik dan dapat dijadikan alternatif inovasi pembelajaran yang berkualitas dapat berdampak langsung pada peningkatan hasil belajar. Secara lebih detail, simpulan di atas di dapat dari simpulan berikut.

1. Hasil validasi perangkat pembelajaran terpadu model networked terintegrasi place-based education yang meliputi silabus, rencana pelaksaan pembelajaran, lembar kegiatan siswa, bahan ajar siswa, bahan ajar siswa menunjukkan bahwa perangkat pembelajaran yang dikembangkan sangat layak dan dapat digunakan;

2. Keterlaksanaan rencana pelaksanaan pembelajaran menunjukkan semua tahapan pada RPP dapat terlaksana dengan baik;

3. Aktivitas siswa menunjukkan siswa aktif (student centered);

4. Tingkat keterbacaan siswa pada penelitian ini menunjukkan siswa ada yang berada pada tingkat independen, instruksional dan frustasi

5. Hambatan dapat terselesaikan dengan baik;

6. Respon siswa yang positif baik pada ujicoba terbatas maupun ujicoba luas; dan

7. Hasil belajar meningkat dengan tinggi pada ujicoba terbatas namun pada ujicoba luas peningkatan hasil belajar belum sesuai dengan harapan yaitu berada pada kategori rendah sampai sedang.

\section{Saran}

Perangkat pembelajaran terpadu model networked terintegrasi place-based education sebaiknya diimplementasikan secara luas terutama di level sekolah dasar oleh guru sebagai alternatif pembelajaran yang menyenangkan, mengasyikkan, dan membetahkan berdasar kesadaran untuk memberikan pelayanan pendidikan yang terbaik bagi peserta didik agar mampu bertahap hidup di abad ke-21 ini.

Perangkat pembelajaran setipe dengan topik yang berbeda perlu dikembangkan oleh peneliti sendiri maupun peneliti lain dengan menggali lebih banyak referensi untuk membantu peserta didik mengembangkan potensi diri 
secara optimal agar maksud dan tujuan pendidikan nasional kita tercapai dengan baik.

Hasil temuan penelitian perlu ditindaklanjuti oleh pihak terkait antara lain dengan guru, sekolah, dan dinas terkait. Guru perlu mereduplikasi pembelajaran sampai dengan tercapainya tujuan pembelajaran dan terjadi peningkatan hasil belajar tinggi. Sekolah perlu membuat program pembiasaan membaca setiap awal jam belajar agar kemampuan membaca siswa meningkat, mengadaan program pelatihan dan pemberdayaan KKG sebagai tempat pengembangan perangkat pembelajaran yang inovatif. Dinas pendidikan perlu mengadakan kerjasama tertulis dengan dinas atau pihak yang terkait dengan pendidikan untuk menyediakan fasilitas baik ahli ataupun hal lain yang berkaitan dengan kebutuhan siswa dalam memeroleh pelayanan pendidikan yang optimal.

\section{DAFTAR PUSTAKA}

Altman, Roberta., Stires Susan., and Weseen, Susan. (2014). Claiming the Promise of Place-Based Education. Occasional Paper Series Bank street College of Education. Vol 33.

Bagus, Suryana Ida; Yudana, Made; Dantes, Rasben Gede. (2014). Kontribusi Kualitas Pembelajaran, Motivasi Belajar, dan Disiplin Belajar terhadap Hasil belajar Seni Budaya kelas VIII SMP Negeri 2 Abiansemal. E-journal Program Pascasarjana Universitas Pendidikan Ganesha Program Studi Administrasi Pendidikan. Vol 5.

Drake, M.Susan. and Burns, C. Rebecca. (2004). Meeting Standards Through Integrated Curriculum. Alexandria, Virginia USA: Association for Supervision and Curriculum.

Feldman. (1994). "Collaborative Inquiry In Networked Communities: Lesson from the Alice Testbed". Paper presented at the Annual Meeting of the American Educational Research Association, New Orleans, LA, April 5-8, 1994)

Fogarty. (1991). The Mindful School. How to Integrate the Curricula. Palatine, Illinois: IRI/ Skylight Publishing, Inc.

Haryati, Mala Ima., Kasdi, Aminuddin., dan Subroto, Tjipto Waspodo. (2014). Pengembangan Perangkat Pembelajaran Terpadu Tipe Threaded untuk Melatih Keterampilan Berfikir Kreatif pada Siswa Sekolah Dasar. Jurnal Kajian Teori dan Hasil Penelitian Pendidikan Dasar. Vol.3 No.1 Juli 2014 pp 01-07.

Hutson, Gareth. (2010). Remembering the Roots of Place Meanings for Place- Based Outdoor Education. New
Zealand Journal of Outdoor Education. Vol 2 No. 4. pp 43-61.

Ibrahim. (2002). Pengembangan Perangkat Pembelajaran. Jakarta: Direktorat SLTP Dirjen Dikdasmen Depdiknas

Khoiriyah, Muhari., dan Subroto, Tjipto Waspodo. (2014). Pengembangan Perangkat Pembelajaran Tematik dengan Pendekatan Saintifik di Sekolah Dasar. Jurnal Kajian Teori dan Hasil Penelitian Pendidikan Dasar. Vol.3 No.1 Juli 2014. pp 12-23.

Limbong, Elymius. (2013). Pengembangan Perangkat Pembelajaran Terpadu Model Networked untuk Sekolah Dasar. (Tesis tidak dipublikasikan). Universitas Negeri Surabaya.

Murtiningsih, Hariyati. (2007). Peningkatan Daya Kreativitas dan Kemandirian Siswa melalui Pembelajaran Terpadu IPS. Jurnal Pendidikan Sekolah Dasar. Volume 8 No.1 Februari 2007.

Peter; Jones, Chris ; Asensio Mireja; Vivien and Steeples; Christine. (2005). Networked Learning in Higher Student's Expectations and Experiences. The International Journal of Higher Education and Educational Planning. Vol 50 No.3.

Prabowo, (2011). Metodologi Penelitian (Sains dan Pendidikan Sains). Surabaya: Unesa University Press.

Smith, A Gregory. and Sobel, David. (2010). Place and Community- Based Education in Schools. New York and London: Rotledge Taylor \& Francis Group.

Sulistyorini, Heni.(2006). Tingkat Keterbacaan Teks dan Pengaruhnya Terhadap Prestasi Belajar Siswa pada Pokok Bahasan Larutan Penyangga di SMA Negeri 1 Kramat Kabupaten Tegal. Skripsi. Universitas Negeri Semarang.

Suryanti. (2008). Pengembangan Perangkat Pembelajaran Tematik untuk Meningkatkan Kualitas Pembelajaran di Kelas Rendah Sekolah Dasar. Jurnal Pendidikan Sekolah Dasar. Vol 5 No.3 Mei 2008 